\title{
Radiofrequency Ablation for Stage I Non-Small Cell Lung Cancer: An Updated Review of Literature from the Last Decade
}

\author{
1) Department of Radiology, Okayama University Medical School, Okayama, Japan \\ 2) Center for Innovative Clinical Medicine, Okayama University Hospital, Okayama, Japan \\ 3) Department of Medical Informatics, Okayama University Hospital, Okayama, Japan
}

\begin{abstract}
Yusuke Matsui ${ }^{1)}$, Toshihiro Iguchi ${ }^{1)}$, Koji Tomita ${ }^{1)}$, Mayu Uka ${ }^{1)}$, Jun Sakurai ${ }^{2)}$, Hideo Gobara ${ }^{3)}$, Susumu Kanazawa ${ }^{1)}$
\end{abstract}

\begin{abstract}
This review summarizes the current findings on radiofrequency ablation (RFA) for stage I non-small cell lung cancer (NSCLC) from relevant literature published in the last decade. While most earlier studies included small populations and had short follow-up periods, more robust data have become available owing to prospective or large cohort studies. The reported overall survival rates after RFA for stage I NSCLC were 83$96 \%, 40-74 \%$, and $23-61 \%$ at 1,3 , and 5 years, respectively, in recent studies. Furthermore, many comparative studies on the outcomes of RFA and stereotactic body radiotherapy have been performed. Most of these studies report no significant difference in survival outcomes between the therapies. Currently, major guidelines define RFA as a reasonable alternative treatment for stage I NSCLC in non-surgical candidates.

Key words: non-small cell lung cancer, early stage, radiofrequency ablation, survival, stereotactic body radiotherapy
\end{abstract}

(Interventional Radiology 2020; 5: 43-49)

\section{Introduction}

Lung cancer remains the most common cancer and is the leading cause of cancer mortality worldwide [1]. Non-small cell lung cancer (NSCLC) accounts for $80 \%$ of all lung cancers [2]. According to the 8th edition of the TNM staging system of the Union for International Cancer Control, stage I NSCLC corresponds to T1 (i.e., tumor of size $\leq 3 \mathrm{~cm}$ and confined to the lung) or T2a (i.e., tumor size ranging from $>$ $3 \mathrm{~cm}$ to $\leq 4 \mathrm{~cm}$, involving the main bronchus or visceral pleura or associated with atelectasis or pneumonitis) tumors and shows no lymph node involvement or distant metastasis [3]. For such early-stage NSCLC, surgical resection is the cornerstone of treatment $[2,4]$. The 5-year survival rate of patients after undergoing resection for stage I NSCLC is re- portedly 66-91\% [5]. However, up to one-fourth of patients with stage I NSCLC are unable to undergo surgery owing to severe comorbidities [6].

Percutaneous ablative therapies are an accepted alternative for the treatment of patients with stage I NSCLC who are not amenable to surgical resection. For the treatment of lung cancer, multiple ablation modalities including radiofrequency ablation (RFA), microwave ablation (MWA), and cryoablation are currently available [7]. Among these, RFA has been the most commonly studied ablative therapy [7]. Since the first report on RFA for lung tumors by Dupuy et al., the safety and efficacy of RFA for NSCLC have been evaluated in many studies [8, 9]. Earlier, most studies included a limited number of patients with short follow-up periods [9]. However, recently, more robust data have become available, including those coming from a few prospective or large co- 
Table 1. Summary of Recent Studies on RFA for Stage I NSCLC

\begin{tabular}{|c|c|c|c|c|c|c|c|c|c|c|c|c|c|}
\hline \multirow{2}{*}{ Author } & \multirow{2}{*}{$\begin{array}{l}\text { Publication } \\
\text { Year }\end{array}$} & \multirow{2}{*}{ Study Design } & \multirow{2}{*}{$\begin{array}{l}\text { No. of } \\
\text { Patients }\end{array}$} & \multirow{2}{*}{ Stage } & \multirow{2}{*}{$\begin{array}{l}\text { Tumor Size } \\
{[\mathrm{mm}]}\end{array}$} & \multirow{2}{*}{$\begin{array}{l}\text { Follow-up } \\
\text { [mo] }\end{array}$} & \multirow{2}{*}{$\begin{array}{l}\text { Local } \\
\text { Tumor } \\
\text { Control [\%] }\end{array}$} & \multirow{2}{*}{$\begin{array}{l}\text { Overall } \\
\text { Survival [mo] }\end{array}$} & \multicolumn{5}{|c|}{$\begin{array}{l}\text { Overall Survival [\%] } \\
\text { (Cancer-specific Survival [\%]) }\end{array}$} \\
\hline & & & & & & & & & 1-year & 2-year & 3-year & 4-year & 5 -year \\
\hline $\begin{array}{l}\text { Lam et al. } \\
{[10]}\end{array}$ & 2018 & NCDB study & 967 & IA & $<30$ & 62.5 (Median) & - & 33.1 (Median) & 85.5 & - & 45.3 & - & 22.5 \\
\hline $\begin{array}{l}\text { Paulussière } \\
\text { et al. [11] }\end{array}$ & 2018 & $\begin{array}{l}\text { Multicenter, } \\
\text { Prospective }\end{array}$ & 32 & IA & 20.7 (Mean) & - & 81.25 & - & 91.67 & - & 58.33 & - & - \\
\hline $\begin{array}{l}\text { Huang et } \\
\text { al. [12] }\end{array}$ & 2018 & $\begin{array}{l}\text { Single-center, } \\
\text { Retrospective }\end{array}$ & 50 & IA & 22 (Mean) & 46.9 (Mean) & 78.9 & 47 (Median) & 96.0 & 86.5 & 67.1 & - & 36.3 \\
\hline $\begin{array}{l}\text { Liu et al. } \\
{[13]}\end{array}$ & 2015 & $\begin{array}{l}\text { Single-center, } \\
\text { Retrospective }\end{array}$ & 29 & $\begin{array}{l}\text { IA or } \\
\text { IB }\end{array}$ & $\begin{array}{l}31 \text { (Mean) } \\
30 \text { (Median) }\end{array}$ & $\begin{array}{l}25 \text { (Mean) } \\
19 \text { (Median) }\end{array}$ & 79.0 & 57 (Mean) & $\begin{array}{l}90.5 \\
(95.2)\end{array}$ & $\begin{array}{l}76.4 \\
(86.6)\end{array}$ & $\begin{array}{l}65.5 \\
(74.2)\end{array}$ & - & - \\
\hline $\begin{array}{l}\text { Dupuy et } \\
\text { al. [14] }\end{array}$ & 2015 & $\begin{array}{l}\text { Multicenter, } \\
\text { Prospective }\end{array}$ & 51 & IA & 20 (Median) & - & 62.7 & - & 86.3 & 69.8 & - & - & - \\
\hline $\begin{array}{l}\text { Lanuti et al. } \\
{[15]}\end{array}$ & 2012 & $\begin{array}{l}\text { Single-center, } \\
\text { Retrospective }\end{array}$ & 45 & $\begin{array}{l}\text { IA or } \\
\text { IB }\end{array}$ & 20 (Mean) & 32 (Median) & 67 & 44.3 (Median) & - & - & 67 & - & 31 \\
\hline $\begin{array}{l}\text { Ambrogi et } \\
\text { al. [16] }\end{array}$ & 2011 & $\begin{array}{l}\text { Single-center, } \\
\text { Prospective }\end{array}$ & 57 & $\begin{array}{l}\text { IA or } \\
\text { IB }\end{array}$ & 26 (Mean) & $\begin{array}{l}47 \text { (Mean) } \\
45.5 \text { (Median) }\end{array}$ & 59.3 & 33.4 (Median) & $\begin{array}{l}83 \\
(89)\end{array}$ & - & $\begin{array}{l}40 \\
(59)\end{array}$ & - & $\begin{array}{l}25 \\
(40)\end{array}$ \\
\hline $\begin{array}{l}\text { Hiraki et al. } \\
{[17]}\end{array}$ & 2011 & $\begin{array}{l}\text { Single-center, } \\
\text { Retrospective }\end{array}$ & 50 & $\begin{array}{l}\text { IA or } \\
\text { IB }\end{array}$ & 21 (Mean) & $\begin{array}{l}39 \text { (Mean) } \\
37 \text { (Median) }\end{array}$ & 69 & $\begin{array}{l}59 \text { (Mean) } \\
67 \text { (Median) }\end{array}$ & $\begin{array}{l}94 \\
(100)\end{array}$ & $\begin{array}{l}86 \\
(93)\end{array}$ & $\begin{array}{l}74 \\
(80)\end{array}$ & $\begin{array}{l}67 \\
(80)\end{array}$ & $\begin{array}{l}61 \\
(74)\end{array}$ \\
\hline
\end{tabular}

RFA $=$ radiofrequency ablation, NSCLC $=$ non-small cell lung cancer, $\mathrm{NCDB}=$ National Cancer Database

hort studies with relatively long follow-up observations. Furthermore, more data are available on the comparison between RFA and stereotactic body radiotherapy (SBRT), another important treatment option for NSCLC.

In this article, we review the current findings available on RFA for stage I NSCLC from the relevant literature published during the last decade.

\section{Literature Search}

A literature search was performed using PubMed in July 2019 using the following key words: "lung cancer" and "radiofrequency ablation." In total, 299 articles were found in the initial search. Of those, 213 were published in the last decade (2010 or later). The titles and abstracts of articles obtained from the initial search were scrutinized to identify relevant studies. In this review, we focused on studies evaluating the outcomes of RFA for stage I NSCLC. Metaanalyses and prospective or retrospective clinical studies with a fair-sized study population $(\mathrm{n} \geq 25)$ were included for review. Case reports and case series with small study populations, and articles written in non-English languages were excluded. Furthermore, a few more recent relevant publications were added during the manuscript preparation and revision process.

\section{Treatment Outcomes after RFA for Stage I NSCLC}

Table 1 shows a summary of the studies that evaluated the treatment outcomes of RFA for stage I NSCLC [10-17]. When multiple reports were published from the same insti- tution or by the same research group, a representative study was selected.

Although most studies were retrospective, Ambrogi et al. reported the results of a prospective single-center study including 57 patients with inoperable NSCLC [16]. The overall survival (OS) and cancer-specific survival (CSS) rates at 1,3 , and 5 years were $83 \%$ and $89 \%, 40 \%$ and $59 \%$, and $25 \%$ and $40 \%$, respectively [16]. More recently, the results from two prospective multicenter studies were reported. In 2015, Dupuy et al. reported the results of the American College of Surgeons Oncology Group (ACOSOG) Z4033 Trial that prospectively evaluated RFA for stage IA NSCLC in medically inoperable patients [14]. The primary objective of their study was to assess the 2-year OS rate after RFA. In 51 eligible patients, the OS rates at 1 and 2 years were $86.3 \%$ and $69.8 \%$, respectively, with the local recurrencefree survival rate at 1 and 2 years of $68.9 \%$ and $59.8 \%$, respectively [14]. Paulussière et al. reported results from a prospective multicenter trial on RFA for stage IA NSCLC in 2018 [11]. For the 32 assessed patients, the 1- and 3-year OS rates were $91.67 \%$ and $58.33 \%$, respectively, while the 1 - and 3-year progression-free survival rates were $71.76 \%$ and $25 \%$, respectively [11].

Among the retrospective studies, a recent study conducted using the National Cancer Database (NCDB) had the largest cohort and the longest follow-up period performed to date [10]. This study included 967 patients with stage I NSCLC who were treated with RFA without chemotherapy or radiotherapy. The 1-, 3-, and 5-year OS rates were $85.5 \%, 45.3 \%$, and $22.5 \%$, respectively, with a median OS of 33.1 months [10]. The other retrospective studies included up to 50 patients with stage I NSCLC, with mean or median follow-up 
periods of 19-47 months $[12,13,15,17]$. In those studies, the median or mean OS was reported to be 44.3-67 months $[12,13,15,17]$. The 1-, 3-, and 5-year OS rates were 90.5$96 \%, 65.5-74 \%$, and $31-61 \%$, respectively $[12,13,15,17]$.

The published reports consistently indicate that local tumor progression (LTP) was the most common type of recurrence after RFA for NSCLC [11, 12, 14-17]. The LTP rates in the reported studies ranged from $19 \%$ to $37 \%$ [11-17]. Tumors larger than $3 \mathrm{~cm}$ can be associated with higher risk of LTP [15]. Studies published in the late 2010s showed relatively low LTP rates of approximately 20\% [11-13]. Considering that the reported LTP rates were $32-42 \%$ for similar-sized tumors (mean 20-26 mm) in the earlier studies published before 2010 [18-20], the LTP rates seem to be reduced in the most recent studies. This may be due to more adequate patient selection and a learning curve effect. Paulussière et al. achieved a 3-year local control rate of $81.25 \%$ using multitined expandable electrodes sized at least $10 \mathrm{~mm}$ larger than the diameter of the target tumor [11]. This method was chosen on the basis of the results of a previous study showing that the application of such a large electrode array was significantly associated with better local efficacy $[21]$.

\section{Prognostic Factors}

As expected, a longer survival could be achieved using RFA in patients with stage IA (T1NOM0) than in those with stage IB (T2aNOM0) tumors. Ambrogi et al. reported that the median OS after RFA was 35 and 20 months in patients with stage IA and IB tumors, respectively, with a significant difference [16]. Liu et al. and Hiraki et al. also showed a tendency of better survival rates in patients with stage IA tumors, but the difference was not significant, presumably because of the small population [13, 17].

In the prospective study conducted by Dupuy et al., a tumor size of $<2 \mathrm{~cm}$ and a performance status of 0 or 1 were significantly associated with better 2-year OS in patients with stage IA who underwent RFA [14]. Huang et al. also showed that tumor size was a prognostic factor after RFA for early-stage NSCLC [12]. In their retrospective study, OS rates in patients with tumors $\leq 2 \mathrm{~cm}(94.7 \%, 89.5 \%, 78.9 \%$, $36.8 \%$, and $10.5 \%$ at $1,2,3,5$ and 10 years, respectively) were significantly better than those in patients with tumors $>2 \mathrm{~cm}(93.5 \%, 83.2 \%, 58.1 \%, 24.2 \%$, and $3.2 \%$ at $1,2,3$, 5 , and 10 years, respectively) [12].

Patient comorbidities also seem relevant to survival. Simon et al. showed that the Charlson Comorbidity Index (CCI), a measuring tool for comorbidities, was a significant predictor of survival in patients who underwent RFA for NSCLC [22]. Most (88\%) of the patients included in their study had stage I tumors. Patients with stage I or II tumors who have a CCI score of $<5$ had a much longer median survival (55.6 and 37.78 months for CCI $1-2$ and 3-4, respectively) than patients who had a score of $\geq 5$ (11.67 months) [22].
Furthermore, treatment at a high-volume center may contribute to better survival. Lam et al. compared survival after RFA for stage IA NSCLC between patients treated at highvolume and non-high-volume centers using NCDB [10]. After propensity score adjustment, significantly better 1-, 3-, and 5-year OS rates $(89.4 \%, 51.2 \%$, and $27.7 \%$, respectively) were observed in patients treated at a high-volume center than in those treated at a non-high-volume center $(85.2 \%, 41.5$, and $19.6 \%$, respectively) [10].

\section{Comparison of the outcomes of RFA and SBRT}

SBRT is another treatment option for patients with stage I NSCLC who are not amenable to surgical treatment [23]. As SBRT and RFA compete with each other, the differences between these therapies have attracted significant interest. Comparative studies between RFA and SBRT are summarized in Table 2 [24-29].

A few researchers have previously attempted to compare these two therapies using published data on the outcomes of each therapy. Bi et al. performed a pooled analysis to compare the outcomes of SBRT and RFA in medically inoperable patients with stage I NSCLC using data from trials published until 2012, including 13 and 31 studies on RFA and SBRT, respectively [27]. The pooled local tumor control rates were higher with SBRT $(97 \%, 88 \%$, and $86 \%$ at 1,3 , and 5 years, respectively) than with RFA $(77 \%, 55 \%$, and $42 \%$ at 1,3 , and 5 years, respectively); the difference remained significant even after adjustment for age and percentage of stage IA [27]. On the other hand, OS rates were not significantly different between the two therapies (1-, 3-, and 5-year OS rates after RFA vs. SBRT were $85 \%$ vs. $85 \%, 53 \%$ vs. $56 \%$, and $32 \%$ vs. $40 \%$, respectively) [27]. Bilal et al. reviewed studies published until 2011 on both RFA and SBRT in inoperable patients with early-stage NSCLC and showed that survival outcomes up to 3 years were similar for RFA and SBRT (3-year OS: 36-87.5\% and 42.7-56\%, respectively), whereas 5-year survival rates were lower after RFA (20.1-27\%) than after SBRT (47\%) [30]. The incidence of LTP tended to be higher after RFA (23.7$43 \%)$ than after SBRT (3.5-14.5\%) [30]. Crabtree et al. compared short-term outcomes of the prospective clinical trials on RFA (ACOSOG trial Z4033), SBRT (Radiation Therapy Oncology Group trial 0236), and sublobar resection (ACOSOG trial Z4032) for stage I NSCLC [31]. The authors showed that the incidence of grade 3 or greater adverse events was not significantly different among these therapies [31].

Several later studies aimed to directly compare the outcomes of the two therapies. Safi et al. compared the outcomes of sublobar resection, RFA, and radiation therapy including SBRT $(57 \%)$ or conventionally fractionated radiotherapy (43\%) for stage I NSCLC [28]. They found no significant difference in OS rates between patients treated with RFA and those treated with radiation therapy: the 1- and 2- 
Interventional Radiology 2020; 5: 43-49

Table 2. Summary of the Comparative Studies on RFA and SBRT

\begin{tabular}{|c|c|c|c|c|c|c|c|c|c|}
\hline \multirow{2}{*}{ Author } & \multirow{2}{*}{$\begin{array}{l}\text { Publication } \\
\text { Year }\end{array}$} & \multirow{2}{*}{ Study Design } & \multirow{2}{*}{$\begin{array}{l}\text { No. of Patients } \\
\text { (RFA vs. SBRT) }\end{array}$} & \multicolumn{3}{|c|}{ Local Tumor Control [\%] } & \multicolumn{3}{|c|}{ Overall Survival [\%] } \\
\hline & & & & RFA & SBRT & $p$-value & RFA & SBRT & $p$-value \\
\hline $\begin{array}{l}\text { Iguchi et al. } \\
{[24]}\end{array}$ & 2020 & $\begin{array}{l}\text { Single-center, } \\
\text { Retrospective }\end{array}$ & 38 vs. 58 & - & - & - & $\begin{array}{l}59.7 \\
\text { at } 5 \text { years }\end{array}$ & $\begin{array}{l}63.7 \\
\text { at } 5 \text { years }\end{array}$ & 0.701 \\
\hline $\begin{array}{l}\text { Lam et al. } \\
{[25]}\end{array}$ & 2018 & NCDB study & 335 vs. 4454 & - & - & - & $\begin{array}{l}89.3 / 52.7 / 27.1 \\
\text { at } 1 / 3 / 5 \text { years }\end{array}$ & $\begin{array}{l}85.5 / 54.3 / 31.9 \\
\text { at } 1 / 3 / 5 \text { years }\end{array}$ & 0.835 \\
\hline $\begin{array}{l}\text { Uhlig et al. } \\
{[26]}\end{array}$ & 2018 & NCDB study & $1102 *$ vs. 27732 & - & - & - & $\begin{array}{l}85.4 / 47.8 / 24.6 \\
\text { at } 1 / 3 / 5 \text { years }\end{array}$ & $\begin{array}{l}86.3 / 45.9 / 26.1 \\
\text { at } 1 / 3 / 5 \text { years }\end{array}$ & 0.694 \\
\hline Bi et al. [27] & 2016 & $\begin{array}{l}\text { Pooled analysis } \\
\text { including } 44 \text { studies }\end{array}$ & 328 vs. 2767 & $\begin{array}{l}77 / 55 / 42 \\
\text { at } 1 / 3 / 5 \text { years }\end{array}$ & $\begin{array}{l}97 / 88 / 86 \\
\text { at } 1 / 3 / 5 \text { years }\end{array}$ & $<0.001$ & $\begin{array}{l}85 / 53 / 32 \\
\text { at } 1 / 3 / 5 \text { years }\end{array}$ & $\begin{array}{l}85 / 56 / 40 \\
\text { at } 1 / 3 / 5 \text { years }\end{array}$ & $>0.05$ \\
\hline $\begin{array}{l}\text { Safi et al. } \\
{[28]}\end{array}$ & 2015 & $\begin{array}{l}\text { Single-center, } \\
\text { Retrospective }\end{array}$ & 25 vs. 49 & - & - & - & $\begin{array}{l}86 / 74 \\
\text { at } 1 / 2 \text { years }\end{array}$ & $\begin{array}{l}93 / 69 \\
\text { at } 1 / 2 \text { years }\end{array}$ & 0.67 \\
\hline $\begin{array}{l}\text { Ochiai et al. } \\
\text { [29] }\end{array}$ & 2015 & $\begin{array}{l}\text { Single-center, } \\
\text { Retrospective }\end{array}$ & 48 vs. 47 & $\begin{array}{l}93.6 / 90.4 \\
\text { at } 1 / 3 \text { years }\end{array}$ & $\begin{array}{l}93 / 93 \\
\text { at } 1 / 3 \text { years }\end{array}$ & 0.746 & $\begin{array}{l}86.4 \\
\text { at } 3 \text { years }\end{array}$ & $\begin{array}{l}79.6 \\
\text { at } 3 \text { years }\end{array}$ & 0.738 \\
\hline
\end{tabular}

$\mathrm{RFA}=$ radiofrequency ablation, $\mathrm{SBRT}=$ stereotactic body radiotherapy, $\mathrm{NCDB}=$ National Cancer Database

*Including RFA and other ablative therapies

year OS rates after RFA vs. RT were $86 \%$ vs. $93 \%$ and $74 \%$ vs. $69 \%$, respectively [28]. Ochiai et al. compared the outcomes of RFA and SBRT for solitary lung tumors sized $\leq 5$ $\mathrm{cm}$ [29]. In their study population, $100 \%$ and $44.7 \%$ of tumors in the RFA and RT groups, respectively, were pathologically proven NSCLC. The cumulative 3-year LTP and OS rates in the RFA vs. SBRT groups were $9.6 \%$ vs. $7.0 \%$ and $86.4 \%$ vs. $79.6 \%$, respectively, with no significant difference [29]. More recently, Iguchi et al. performed propensity score-matched analyses to compare survival rates after RFA, SBRT, and sublobar resection for stage I NSCLC in their single-center retrospective study [24]. After propensity score correction, OS and progression-free survival (PFS) rates were not significantly different between RFA and SBRT (5-year OS [PFS] was $59.7 \%$ [35.9\%] vs. $63.7 \%$ [55.7\%] after RFA vs. SBRT, respectively) [24].

Furthermore, two large comparative studies examining ablative therapy and SBRT have been recently published [25, 26]. The studies used NCDB to compare mid- to long-term survival between the two therapies. Lam et al. performed a propensity score-matched analysis using NCDB to compare OS rates after RFA for stage I NSCLC with that after SBRT [25]. No significant difference in OS rates was found between the RFA cohort including 335 patients (1-, 3-, and 5year OS: $89.3 \%, 52.7 \%$, and $27.1 \%$, respectively) and the SBRT cohort including 4454 patients (1-, 3-, and 5-year OS: $85.5 \%, 54.3 \%$, and $31.9 \%$, respectively) [25]. Uhlig et al. selected patients with stage I NSCLC who were treated with thermal ablation including RFA and other ablative therapies ( $n=1102)$ and SBRT $(n=27732)$ from the NCDB to compare their outcomes [26]. The thermal ablation group was associated with more comorbidities and a smaller tumor. OS rates in the propensity score-matched cohort were not significantly different between thermal ablation (1-, 3-, and 5year OS: $85.4 \%, 47.8 \%$, and $24.6 \%$, respectively) and SBRT (1-, 3-, and 5-year OS: $86.3 \%, 45.9 \%$, and $26.1 \%$, respectively) [26].
To date, there have been no randomized trials comparing RFA and SBRT for stage I NSCLC. Although some studies have suggested better local tumor control with SBRT, no apparent superiority of either therapy has been shown regarding the survival outcomes. The repeatability of RFA may contribute to the comparable survival with SBRT [29]. In current clinical practice, patients may be selected for each therapy on a case-by-case basis, considering not only the treatment efficacy but also the difference in other factors between those therapies, including adverse events, treatment cost, duration of therapy, effect on pulmonary function, and quality of life after treatment. The common adverse events of RFA include pneumothorax, pleural effusion, and hemorrhage [32]. On the other hand, the common toxicities of SBRT include fatigue, dyspnea, chest pain, pneumonitis, and pneumonia [33]. Most of the RFA-related adverse events occur shortly after treatment and may cause a higher risk of unplanned readmission during an early postoperative period, while the toxicities of SBRT may manifest over a prolonged post-treatment period [25, 26]. Further studies are warranted for optimal patient selection with a better understanding of the relative efficacy and safety of each therapy.

\section{Comparison of the outcomes of RFA and the other ablative therapies}

MWA is another heat-based ablative treatment modality for lung cancers. MWA devices create an electromagnetic field to cause frictional heat through the rotating water molecules, depending less on electric and thermal conduction into tissues [34]. Therefore, the heat sink effect may be less in MWA than in RFA [34]. In a retrospective study including 47 medically inoperable patients with stage I NSCLC, the local control rates at 1, 3, and 5 years after MWA were $96 \%, 64 \%$, and $48 \%$, respectively [35]. In the same study, the 1-, 3-, and 5-year OS rates were $89 \%, 43 \%$, and $16 \%$, respectively [35]. Currently, comparative studies 
between RFA and MWA for lung cancers remain sparse. Only a few recent studies have compared the outcomes of RFA for primary lung cancer with those of MWA. Narsule et al. compared LTP and survival between patients who underwent RFA $(n=21)$ and MWA $(n=4)$ for stage IA NSCLC [36]. They found no significant difference in median time to local progression (35 months vs. 50 months after RFA vs. MWA) or median survival (36 vs. 17 months after RFA vs. MWA) [36]. Yuan et al. compared survival outcome after RFA and MWA for primary lung cancer by meta-analysis [37]. They found no significant difference in median OS between the RFA (28.4 months) and MWA (24.4 months) groups [37]. Although other studies have shown comparative data between RFA and MWA, they used heterogeneous populations comprising patients with primary lung cancer and various metastatic lung tumors [38, 39].

Cryoablation has also been applied for the treatment of NSCLC [40, 41]. Cryoablation involves the use of low temperatures of $-20^{\circ} \mathrm{C}$ to $-40^{\circ} \mathrm{C}$ to destroy tumor cells through multiple mechanisms, including cell dehydration due to osmotic shifts in intracellular and extracellular water, disruption of cell membranes and organelles by intracellular ice formation, ischemia caused by microvascular thrombosis, and so forth [40, 41]. Yamauchi et al. retrospectively evaluated the midterm results of cryoablation in 22 patients with medically inoperable stage I NSCLC [42]. The 2- and 3year OS rates in their study population were $88 \%$ and $88 \%$, respectively, with LTP observed in $3 \%$ of the treated tumors [42]. Another retrospective study conducted by Moore et al. showed the long-term survival after cryoablation for stage I NSCLC [43]. In their study including 45 patients, the 1-, 3-, and 5-year OS rates were $89.4 \%, 78.1 \%$, and $67.8 \%$, respectively, with LTP observed in $14.9 \%$ of the tumors [43]. Zemlyak et al. compared survival outcomes among patients with stage I NSCLC who underwent sublobar resections, RFA, and cryoablation [44]. The 3-year OS rates for sublobar resections $(\mathrm{n}=25)$, RFA $(\mathrm{n}=12)$, and cryoablation $(\mathrm{n}=$ 27) groups were $87.1 \%, 87.5 \%$, and $77 \%$, respectively, with no significant difference among the three groups [44].

The common adverse events of MWA and cryoablation are similar to those of RFA, including pneumothorax, pleural effusion, and hemorrhage [37, 40]. In the meta-analysis performed by Yuan et al., the incidences of pneumothorax and pleural effusion were not significantly different between the RFA and MWA groups [37].

To date, robust comparative data regarding the difference in the efficacy and safety of RFA, MWA, and cryoablation for the treatment of early-stage NSCLC are still lacking, and this topic remains to be investigated.

\section{Statements on RFA for stage I NSCLC in Current Clinical Guidelines}

The American College of Chest Physicians (ACCP) evidence-based clinical practice guidelines suggest that RFA may be considered for peripheral tumors less than $3 \mathrm{~cm}$ in inoperable patients with stage I NSCLC [45]. Similarly, the consensus statement of the ACCP and Society of Thoracic Surgeons defines RFA as a reasonable treatment option for high-risk patients with stage I NSCLC who have a tumor less than $3 \mathrm{~cm}$, while also indicating that inferior primary tumor control limits the use of RFA to patients who are not candidates for SBRT or sublobar resection [6].

The European Society for Medical Oncology clinical practice guidelines for NSCLC published in 2017 indicate RFA as a reasonable alternative for patients with stage I NSCLC who have strong contraindications for surgery and SBRT, noting that the evidence comes from observational studies only [4].

In the National Comprehensive Cancer Network guidelines version 1.2020, definitive radiation therapy including SBRT is recommended for medically inoperable patients with stage IA NSCLC, and image-guided thermal ablation is noted as an option for selected patients [46].

\section{Conclusion}

The usefulness of RFA in treating patients with stage I NSCLC has been shown in many studies in approximately 20 years, since its introduction for the treatment of lung cancers. Although most studies conducted in the earlier years were small observational ones, data from prospective or large cohort studies have become available in the last decade. Currently, representative guidelines define RFA as a reasonable alternative for stage I NSCLC in non-surgical candidates. Continuous data accumulation through further studies, e.g., prospective comparative trials with SBRT, is needed to determine the role of RFA in the management of stage I NSCLC based on high-level evidence.

Conflict of interest: The authors declare that they have no conflicts of interest concerning this manuscript.

\section{References}

1. Bray F, Ferlay J, Soerjomataram I, Siegel RL, Torre LA, Jemal A. Global Cancer Statistics 2018: GLOBOCAN estimates of incidence and mortality worldwide for 36 cancers in 185 countries. CA Cancer J Clin 2018; 68: 394-424.

2. Lavaud P, Besse B, de Baere T, Deschamps F, Mussot S, Le Pechoux $\mathrm{C}$, et al. Focus on recommendations for the management of non-small cell lung cancer. Cardiovasc Intervent Radiol 2019; 42: 1230-1239.

3. Goldstraw P, Chansky K, Crowley J, Rami-Porta R, Asamura H, Eberhardt WEE, et al. The IASLC Lung Cancer Staging Project: proposals for revision of the TNM stage groupings in the forthcoming (Eighth) edition of the TNM classification for lung cancer. J Thorac Oncol 2016; 11: 39-51.

4. Postmus PE, Kerr KM, Oudkerk M, Senan S, Waller DA, Vansteenkiste $\mathrm{J}$, et al. Early and locally advanced non-small-cell lung cancer (NSCLC): ESMO Clinical Practice Guidelines for diagnosis, treatment and follow-up. Ann Oncol 2017; 28: iv1-iv21.

5. Rami-Porta R, Bolejack V, Crowley J, Ball D, Kim J, Lyons G, et al. The IASLC lung cancer staging project: Proposals for the revisions of the $\mathrm{T}$ descriptors in the forthcoming eighth edition of the 
TNM classification for lung cancer. J Thorac Oncol 2015; 10: 990-1003.

6. Donington J, Ferguson M, Mazzone P, Handy J, Schuchert M, Fernando $\mathrm{H}$, et al. American College of Chest Physicians and Society of Thoracic Surgeons Consensus statement for evaluation and management for high-risk patients with stage I non-small cell lung cancer. Chest 2012; 142: 1620-1635.

7. de Baere T, Tselikas L, Catena V, Buy X, Deschamps F, Palussière J. Percutaneous thermal ablation of primary lung cancer. Diagn Interv Imaging 2016; 97: 1019-1024.

8. Dupuy DE, Zagoria RJ, Akerley W, Mayo-smith WW, Kavanagh P $\mathrm{V}$, Safran H. Percutaneous radiofrequency ablation of malignancies in the lung. AJR Am J Roentgenol 2000; 174: 57-59

9. Hiraki T, Gobara H, Iguchi T, Fujiwara H, Matsui Y, Kanazawa S. Radiofrequency ablation for early-stage non-small cell lung cancer. Biomed Res Int 2014; 2014: 152087.

10. Lam A, Yoshida EJ, Bui K, Katrivesis J, Fernando D, Nelson K, et al. Patient and facility demographics related outcomes in earlystage non-small cell lung cancer treated with radiofrequency ablation: a National Cancer Database analysis. J Vasc Interv Radiol 2018; 29: 1535-1541.e2.

11. Palussière J, Chomy F, Savina M, Deschamps F, Gaubert JY, Renault A, et al. Radiofrequency ablation of stage IA non-small cell lung cancer in patients ineligible for surgery: results of a prospective multicenter phase II trial. J Cardiothorac Surg 2018; 13: 91.

12. Huang B-Y, Li X-M, Song X-Y, Zhou J-J, Shao Z, Yu Z-Q, et al. Long-term results of CT-guided percutaneous radiofrequency ablation of inoperable patients with stage Ia non-small cell lung cancer: a retrospective cohort study. Int J Surg 2018; 53: 143-150.

13. Liu B, Liu L, Hu M, Qian K, Li Y. Percutaneous radiofrequency ablation for medically inoperable patients with clinical stage I non-small cell lung cancer. Thorac Cancer 2015; 6: 327-333.

14. Dupuy DE, Fernando HC, Hillman S, Ng T, Tan AD, Sharma A, et al. Radiofrequency ablation of stage IA non-small cell lung cancer in medically inoperable patients: results from the American College of Surgeons Oncology Group Z4033 (Alliance) trial. Cancer $2015 ; 121: 3491-3498$.

15. Lanuti M, Sharma A, Willers H, Digumarthy SR, Mathisen DJ, Shepard J-AO. Radiofrequency ablation for stage I non-small cell lung cancer: management of locoregional recurrence. Ann Thorac Surg 2012; 93: 921-988.

16. Ambrogi MC, Fanucchi O, Cioni R, Dini P, De Liperi A, Cappelli $\mathrm{C}$, et al. Long-term results of radiofrequency ablation treatment of stage I non-small cell lung cancer: a prospective intention-to-treat study. J Thorac Oncol 2011; 6: 2044-2051.

17. Hiraki T, Gobara H, Mimura H, Matsui Y, Toyooka S, Kanazawa S. Percutaneous radiofrequency ablation of clinical stage I nonsmall cell lung cancer. J Thorac Cardiovasc Surg 2011; 142: 2430.

18. Pennathur A, Luketich JD, Abbas G, Chen M, Fernando HC, Gooding WE, et al. Radiofrequency ablation for the treatment of stage I non-small cell lung cancer in high-risk patients. J Thorac Cardiovasc Surg 2007; 134: 857-864.

19. Hiraki T, Gobara H, Iishi T, Sano Y, Iguchi T, Fujiwara H, et al. Percutaneous radiofrequency ablation for clinical stage I non-small cell lung cancer: results in 20 nonsurgical candidates. J Thorac Cardiovasc Surg 2007; 134: 1306-1312.

20. Lanuti M, Sharma A, Digumarthy SR, Wright CD, Donahue DM, Wain JC, et al. Radiofrequency ablation for treatment of medically inoperable stage I non-small cell lung cancer. J Thorac Cardiovasc Surg 2009; 137: 160-166.
21. Ihara $H$, Gobara H, Hiraki $T$, Mitsuhashi $T$, Iguchi $T$, Fujiwara H, et al. Radiofrequency ablation of lung tumors using a multitined expandable electrode: impact of the electrode array diameter on local tumor progression. J Vasc Interv Radiol. 2016; 27: 87-95.

22. Simon TG, Beland MD, Machan JT, Dipetrillo T, Dupuy DE. Charlson Comorbidity Index predicts patient outcome, in cases of inoperable non-small cell lung cancer treated with radiofrequency ablation. Eur J Radiol 2012; 81: 4167-4172.

23. Schneider BJ, Daly ME, Kennedy EB, Antonoff MB, Broderick S, Feldman J, et al. Stereotactic body radiotherapy for early-stage non-small-cell lung cancer: American Society of Clinical Oncology Endorsement of the American Society for Radiation Oncology evidence-based guideline. J Clin Oncol 2018; 36: 710-719.

24. Iguchi T, Hiraki T, Matsui Y, Mitsuhashi T, Katayama N, Katsui $\mathrm{K}$, et al. Survival outcomes of treatment with radiofrequency ablation, stereotactic body radiotherapy, or sublobar resection for patients with clinical stage I non-small-cell lung cancer: a singlecenter evaluation. J Vasc Interv Radiol in press.

25. Lam A, Yoshida EJ, Bui K, Fernando D, Nelson K, Abi-Jaoudeh N. A National Cancer Database analysis of radiofrequency ablation versus stereotactic body radiotherapy in early-stage non-small cell lung cancer. J Vasc Interv Radiol 2018; 29: 1211-1217.e1.

26. Uhlig J, Ludwig JM, Goldberg SB, Chiang A, Blasberg JD, Kim HS. Survival rates after thermal ablation versus stereotactic radiation therapy for stage 1 non-small cell lung cancer: A National Cancer Database study. Radiology 2018; 289: 862-870.

27. Bi N, Shedden K, Zheng X, Kong FMS. Comparison of the effectiveness of radiofrequency ablation with stereotactic body radiation therapy in inoperable stage I non-small cell lung cancer: a systemic review and pooled analysis. Int J Radiat Oncol Biol Phys 2016; 95: 1378-1390.

28. Safi S, Rauch G, op den Winkel J, Kunz J, Schneider T, Bischof $\mathrm{M}$, et al. Sublobar resection, radiofrequency ablation or radiotherapy in stage I non-small cell lung cancer. Respiration. 2015; 89: 550-557.

29. Ochiai S, Yamakado K, Kodama H, Nomoto Y, Ii N, Takaki H, et al. Comparison of therapeutic results from radiofrequency ablation and stereotactic body radiotherapy in solitary lung tumors measuring $5 \mathrm{~cm}$ or smaller. Int J Clin Oncol 2015; 20: 499-507.

30. Bilal H, Mahmood S, Rajashanker B, Shah R. Is radiofrequency ablation more effective than stereotactic ablative radiotherapy in patients with early stage medically inoperable non-small cell lung cancer? Interact Cardiovasc Thorac Surg 2012; 15: 258-265.

31. Crabtree T, Puri V, Timmerman R, Fernando H, Bradley J, Decker $\mathrm{PA}$, et al. Treatment of stage I lung cancer in high-risk and inoperable patients: comparison of prospective clinical trials using stereotactic body radiotherapy (RTOG 0236), sublobar resection (ACOSOG Z4032), and radiofrequency ablation (ACOSOG Z 4033). J Thorac Cardiovasc Surg 2013; 145: 692-699

32. Hiraki T, Gobara H, Fujiwara H, Ishii H, Tomita K, Uka M, et al. Lung cancer ablation: Complications. Semin Intervent Radiol 2013; 30: 169-175.

33. Murray P, Franks K, Hanna GG. A systematic review of outcomes following stereotactic ablative radiotherapy in the treatment of early-stage primary lung cancer. Br J Radiol 2017; 90: 20160732.

34. Palussière J, Catena V, Buy X. Percutaneous thermal ablation of lung tumors - radiofrequency, microwave and cryotherapy: where are we going? Diagn Interv Imaging 2017; 98: 619-625

35. Yang X, Ye X, Zheng A, Huang G, Ni X, Wang J, et al. Percutaneous microwave ablation of stage I medically inoperable nonsmall cell lung cancer: clinical evaluation of 47 cases. J Surg Oncol. 2014; 110: 758-763. 
36. Narsule CK, Sridhar P, Nair D, Gupta A, Oommen RG, Ebright MI, et al. Percutaneous thermal ablation for stage IA non-small cell lung cancer: long-term follow-up. J Thorac Dis 2017; 9: 4039-4045.

37. Yuan Z, Wang Y, Zhang J, Zheng J, Li W. A meta-analysis of clinical outcomes after radiofrequency ablation and microwave ablation for lung cancer and pulmonary metastases. J Am Coll Radiol 2019; 16: 302-314.

38. Jiang B, Mcclure MA, Chen T, Chen S. Efficacy and safety of thermal ablation of lung malignancies: a network meta-analysis. Ann Thorac Med 2018; 13: 243-250.

39. Chi J, Ding M, Shi Y, Wang T, Cui D, Tang X, et al. Comparison study of computed tomography-guided radiofrequency and microwave ablation for pulmonary tumors: a retrospective, casecontrolled observational study. Thorac Cancer. 2018; 9: 12411248.

40. Inoue M, Nakatsuka S, Jinzaki M. Cryoablation of early-stage primary lung cancer. Biomed Res Int 2014; 2014: 521691.

41. Zhang YS, Niu LZ, Zhan K, Li ZH, Huang YG, Yang Y, et al. Percutaneous imaging-guided cryoablation for lung cancer. J Thorac Dis. 2016; 8: S705-S709.

42. Yamauchi $Y$, Izumi $Y$, Hashimoto $K$, Yashiro H, Inoue M, Nakatsuka S, et al. Percutaneous cryoablation for the treatment of medi- cally inoperable stage I non-small cell lung cancer. PLoS One 2012; 7: e33223.

43. Moore $\mathrm{W}$, Talati R, Bhattacharji $\mathrm{P}$, Bilfinger T. Five-year survival after cryoablation of stage I non-small cell lung cancer in medically inoperable patients. J Vasc Interv Radiol 2015; 26: 312-319.

44. Zemlyak A, Moore WH, Bilfinger TV. Comparison of survival after sublobar resections and ablative therapies for stage I non-small cell lung cancer. J Am Coll Surg 2010; 211: 68-72.

45. Howington JA, Blum MG, Chang AC, Balekian AA, Murthy SC. Treatment of stage I and II non-small cell lung cancer: diagnosis and management of lung cancer, 3rd ed: American College of Chest Physicians evidence-based clinical practice guidelines. Chest 2013; 143: e278S-e313S.

46. National Comprehensive Cancer Network (NCCN). NCCN Clinical Practice Guidelines in Oncology. Non-Small Cell Lung Cancer Version 1.2020. 2019 November 6 [cited 2019 Dec 10]. Available from: https://www.nccn.org/professionals/physician_gls/default. aspx\#nscl.

Interventional Radiology is an Open Access journal distributed under the Creative Commons Attribution-NonCommercial 4.0 International License. To view the details of this license, please visit (https://creativecommons.org/licenses/bync/4.0/). 